\title{
Competitive Potential of Micro-sized IT Outsourcing Vendors in a Small State of the European Union: A Case of Malta
}

\author{
Keith Cilia De Bono, Dragan Nikolik and Silvio De Bono \\ Maastricht School of Management, Netherlands
}

\begin{abstract}
Information Technology (IT) outsourcing becomes an increasingly popular phenomenon among business practitioners who seek services and/or products of third party suppliers to meet their in-house IT needs. It offers a business opportunity for IT outsourcing vendors, which, from a competitive potential perspective, may be challenging when such organisations are micro-enterprises (employing not more than ten employees) and operate from Malta - a developing micro island state in the Mediterranean and a constituent part of the European Union. This paper tests the notion of competitive potential as posed by the Strategic Alignment Model (SAM) of Henderson and Venkatraman (1993), within such particular context. Through the SAM, competitive potential is viewed as a strategic co-alignment of a firm's business strategy, IT strategy and organisation infrastructure. A best fit model which positively asserts such a notion is derived from Structural Equation Modelling (SEM) that is applied to data collected from a survey amongst the Maltese IT outsourcing micro-enterprises. The model is validated and confirmed through a Case Study involving six micro-enterprises. The paper indicates the strategic alignment of competitive, organisational and strategic factors, which, albeit not often explicit, are highly active in IT outsourcing micro-enterprises. It also indicates that competitive potential in the IT outsourcing micro-enterprises is a dynamic capability that evolves out of a well conceived business strategy, IT strategy and organisation infrastructure which seek to exploit existing competitive potential and compensate for resource constraints whilst seeking to deliver IT service and/or product through outsourcing arrangements.
\end{abstract}

Keywords: micro-sized organisations, vendor's perspective, competitive potential, IT outsourcing

\section{Introduction}

The outsourcing of Information Technology (IT) products and services as integral part of an organisation's IT strategy is a rapidly growing phenomenon (Strivastava et al., 2010) along with other prevalent trends in globalisation (Tonurist, 2010). By the end of 2007 the value of the total worldwide outsourcing market, including IT outsourcing and business process outsourcing, is placed at almost US $\$ 300$ billion-an increase of about $19 \%$ over the previous year. Even at the height of the global economic downturn, the 'global expenditure in the IT industry on outsourcing was projected to fall slower than the 10 percent decline forecast for 2009' (Heath, 2009).

In the pursuit of improving their economic power, regional blocks are increasingly seeking ways of gaining a competitive edge in a global economy. The exploitation of IT is a key approach applied to reach this goal (Tonurist, 2010). The Lisbon Strategy, 
agreed to by the EU in 2000 , has sought to make the region 'the most competitive and dynamic knowledge based economy in the world' over a number of years. Within the context of Malta, an EU member state, this has been further complemented by the Smart Island Strategy, Government's National ICT programme which places the Information Technology industry as 'a main pillar of the economy' with Malta becoming 'one of the top ten information societies in the world'. Furthermore, the Government of Malta has formulated a National Programme, entitled Vision 2015 which outlines a nation-wide five-year approach towards sustainable development and through which Information and Communications Technology is confirmed as one of a number of main thrusts of future economic activity and management support industries (Government of Malta, 2010).

Malta is a small island state in the Mediterranean region situated between Southern Europe and North Africa. Its size is around 316 square kilometres and it has a population of around 420,000. Malta joined the European Union in May 2004 and adopted the euro as its national currency in January 2008. In 2003, 70 percent of Malta's foreign trade was attributed to the European Union (EU) and by 2002, 40 percent of the Maltese GDP factor cost was contributed by the market services sector (Briguglio and Cordina, 2004). The Maltese market is largely made up of Small to Medium sized enterprises (SMEs) including micro-sized firms (firms employing not more than ten employees) ranging from manufacturing to market services. Coupled with the expansion of the tertiary sector during the past decade, is the growth of the IT sector in the Maltese economy. In 2004, it was reported that over 96 percent of Maltese organisations use IT; and that around 51 to 67 percent of such firms use IT management systems for orders or purchases (National Statistics Office, 2005). In 2007, a total 126 organisations, mostly micro sized firms were known to be IT service providers in Malta (MITI, 2007). In 2009, Malta's competitiveness ranked $52^{\text {nd }}$ position from a total of 133 countries, with positive trends noted in areas that include educational services, technological readiness and quality of national business environment (World Economic Forum, 2010).

Indeed, the competitive potential of a small island state in any particular industry may be challenging and particularly intriguing. Whilst not discounting 'debilitating effects of smallness, especially where coupled with lack of resources and remoteness', Baldacchino (1999) argues that 'small nations are ideal subjects for fine-tuning the internal and external balances necessary to secure competitiveness' and that, 'despite the real difficulties faced, there exist some successful local ventures in these small insular locations'. Compounded with the smallness of the country, consideration also needs to be made of the IT outsourcing industry which in itself entails a significant degree of business uncertainty (Simons, 2002; Johnson and Scholes, 1993) as well as of the smallness of the firms operating in Malta.

Additionally, van Dijk (2000) refers to the assertion by Porter (1990) that there needs to be a shift in focus 'from the macro to the micro-foundations of competitive potential' given that enterprises compete and that they are 'the agents of growth and dynamism' (p.9). Looking from a microperspective of competitive potential as suggested by Porter (1990), this calls for the need to look into the key dynamics that constitute the essence and viability of a firm in a competitive environment. Within the context of IT outsourcing there is more to it than the technology itself, 'the people and organisational structures cannot be forgotten or put out of the equation' (Windrum and Berranger, 2002). Hence a study of the competitive potential of IT outsourcing vendors needs to include:

- the firm's organisation structure, including staffing and management style issues

- its business strategy, representing its strategic direction 
- its IT strategy, including information systems which complement the firm's operations to reach its strategic objectives.

The aim of this paper is thus to report the findings of a deductive and inductive research about the competitive potential of micro sized IT outsourcing vendors in Malta, carried out in July 2007. In the process, the following research question has been adopted as a basis for the study:

Is the competitive potential of micro enterprise IT outsourcing vendor firms in Malta positively impacted upon by the strategic alignment of the firms' IT strategy, business strategy and their organisation infrastructure?

Most literature on the subject tends to focus on large organisations and even in those studies on smaller organisations, 'most do not differentiate between microfirms and SMEs' (Packalen, 2010). From an academic perspective, Cragg and Todorova (2005) argue that previous research has indicated that what has been applicable for large firms cannot be made necessarily applicable to small firms. Various sources such as Packalen (2010), Korvela and Packalen (2010) and Sum et al. (2004) even assert that the needs and support of micro-enterprises differ significantly from larger (albeit small) organisations in terms of for example, finance and resource availability. Micro-enterprises cannot be ignored particularly considering that out of 99 percent of enterprises in Europe being accounted as SMEs in 2010, 90 percent of them are micro-enterprises which contribute to 53 percent of employment in Europe (European Commission, 2010). More specifically, apart from the European context of which Malta forms part, within the Mediterranean scenario, it is argued by van Dijk (2000) that sparse studies have been conducted within the latter region.

As a developing economy, it is also argued that findings cited in the case of SMEs within developed countries cannot be simply generalised for the Malta case. Kapurubandara and Lawson (2006) specifically contend that 'SMEs in developing countries are faced with barriers that are specific to them, some more pronounced than would be in the case for SMEs in developed countries'. Moreover, it is also argued that literature on small firms, especially including operations of micro-enterprises in small developing countries is sparse (Streeten, 1993; Hadjimanolis, 2000; Prasad and Tata, 2009).

Finally, it has also been noted that literature on IT outsourcing tends to focus on the demand perspective, as also noted by Levina and Ross (2003). This paper therefore, seeks to fill up the gap by looking into the subject area from a micro sized IT outsourcing vendor point of view in a developing small island state.

\section{The Context}

As noted throughout this paper, the context of micro-enterprises operating within a small island state shall be kept in view. Tonurist (2010) contends that indeed, the population size and availability of resources do influence the economy of a state. However, he argues that the ability to find niches and context specific solutions within a changing global society is not out of reach, even within a small country. Indeed, micro-enterprises can be distinguished from larger companies by their flexibility, apart from volatility, skill constraints, market power limitations and market behaviours mainly affected by partners or competitors (Chen et al., 2006). According to Ang (1991), microenterprises can be distinguished from larger firms within the context of financial management, considering the fact that their securities are not publicly traded, owner investments are undiversified, and limited liability is rarely present in a true economic sense. Holmes and Gibson (2001) specifically refer to informal relationships within such firms, even if management and ownership are separate. The degree of informality in these firms may be such that strategic considerations, albeit existing, may not be distinguishable at all. Such parameters, prevalent within microenterprises, are likely to become evident throughout the course of this paper. 


\section{Conceptual Framework}

In achieving the purpose of this paper, various theoretical models have been considered. Though none of these models fitted the research purpose since these were generally based on a much larger context - both in size of the firm and of the country - the Strategic Alignment model presented by Henderson and Venkatraman
(1993) was adopted as a basic theoretical framework because it gave equal priority to the various dimensions considered in this paper as indicated in the conceptual model shown in Figure 1. The conceptual model has also defined the constructs through tested measures applied from various sources, explained further in this paper.

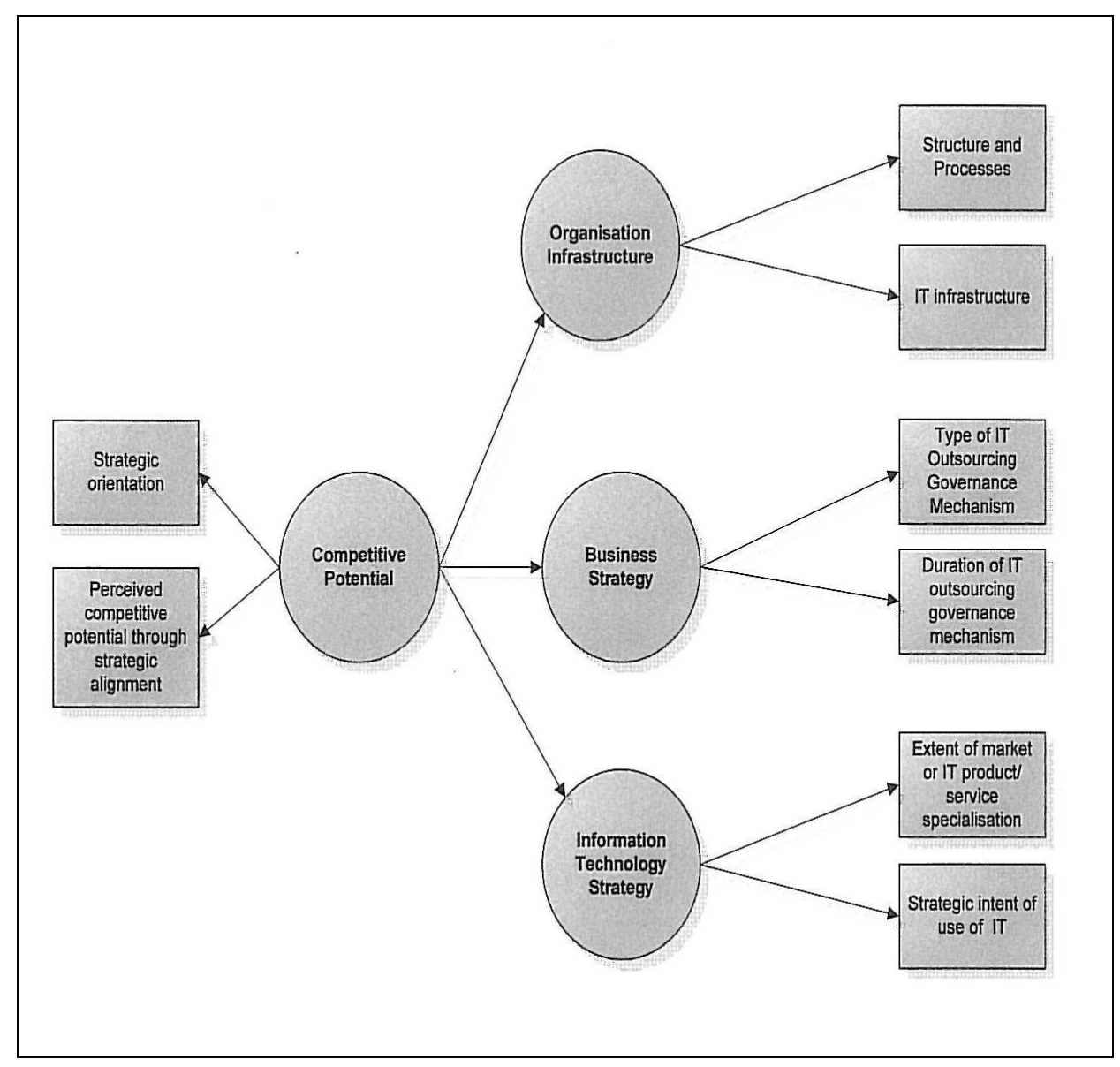

Fig 1. Conceptual Model

The Strategic Alignment model is based upon strategic alignment - viewed as emergent by (Henderson and Venkatraman, 1993; Kefi and Kalika, 2005) and important at both IS and senior executive management level (Brancheau et al, 1996; Gottschalk, 2000; Hartog and Herbert, 1986; Neiderman et al., 1991). A number of research studies have been noted to adopt Henderson and Venkatraman (1993)'s Strategic Alignment model, as confirmed by Chan and Reich (2007). Related studies include those of Chevez (2010); Hooper et al. (2010); Muhamad and Ashari (2005); Beeson and Al Mahamid (2004); Bergeron et al. (2003) and Jouirou and Kalika (2004) which involve small to medium sized enterprises and Kefi and Kalika (2005) involving a number of international European companies; 
Thus, the conceptual model, through its constructs and indicators, basically represents competitive potential as a strategic co-alignment, whereby the IT strategy is defined as the 'anchor domain the domain that has the greatest strength' whilst the business strategy is the 'pivot domain - the weaker quadrant which will receive focus and where changes will be addressed by the anchor domain' and the organisation infrastructure is defined as the impacted domain as it is 'directly affected by change to the pivot domain' (Henderson and Venkatraman, 1993; Luftman, Lewis and Oldach, 1993; Paap, 2002). Initial considerations have also been made to an alternative representation of the Strategic alignment model for competitive potential whereby strategic alignment is explictly represented as a higher, second-order construct, that needs to be inferred from the latent constructsBusiness Strategy, IT Strategy and Organisation infrastructure. However practical and empirical considerations have given rise to the proposed model whereby strategic alignment is represented as an indicator of a construct. As indicated by Cumps et al (2008) and Chen and Tsou (2007), there does not appear to be a hard or fast rule in academic literature on how to precisely measure alignment, and particularly in small firms (Cragg and Todorova, 2005). Examples of studies that present strategic coalignment or similar abstract concepts (e.g. success) as an indicator of a construct, rather than as a construct in its own right, include those by McHaney (2000), Tanriverdi (2005) and Chen and Tsou (2007).

\section{Competitive Potential, as Viewed through the Strategic Alignment Model}

Competitive potential is often viewed as a key objective to be achieved from IT outsourcing arrangements within organisations (Kudelski et al., 2005) and reported to positively relate to business performance (Hartog and Herbert, 1986; Neiderman et al., 1991; Kearns and Lederer, 2000). van Dijk (2000) defines it as the 'capacity to gain, maintain and expand its share in markets for final products'. Henderson and Venkatraman's Strategic Alignment Model (1993) views competitive potential as a business perspective that focuses on how emerging information technologies applied by a firm's top management can influence and enable new business strategies within firms (Papp, 2001), leading to competitive advantage (Barua et al, 1995; Katz, 1993; LaPlante, 1994). The changes in the business strategy are in turn claimed to have an impact on the firm's business (organisational) infrastructure (Henderson \& Venkatraman, 1993; Luftman, Lewis \& Oldach, 1993).

Kefi et al (2005) have applied a multidimensional perspective (which includes competitive potential) to measure business performance. The tool is based on a subjective approach. Strategic management researchers frequently propose and apply a subjective approach to measure business performance (Bergeron et al, 2003; Jouirou et al, 2004, Kefi et al, $2005)$, given that actual information on this topic may be very sensitive for dissemination by the companies. This trait is not uncommon in small organizations. Thus, the measures applied by Kefi et al (2005) to measure business performance are those developed by Henderson and Venkatraman (1993) and applied by various researchers. The measure, also applied for competitive potential in the conceptual diagram above, refers to the vendor's strategic orientation based on one of the following: individual productivity, cost reduction, innovation capabilities, reactivity, responsiveness to customer requirements and collaborative relationships with business partners. The competitive potential construct is also measured by its perception among vendors as being a strategic coalignment of business and IT strategy and organisation infrastructure - in line with Henderson and Venkatraman's postulation.

\section{Business Strategy}

According to Henderson and Venkatraman (1993), the business strategy is 'concerned with decisions such as product-market offering and the distinctive strategy attributes that differentiate the firm from its competitors, as well as the range of make-versus-buy decisions including partnerships and alliances'. From a pragmatic point of view, this paper will 
focus on how the IT outsourcing vendor achieves its firm's business strategy in the conduct of outsourcing, through the latter inter-organisational methods or as better termed as 'governance mechanisms'. The governance mechanism for IT outsourcing is defined:

- As the terms of a transaction, under Transaction Cost Theory (TCT) whereby the transaction occurs when a good or service is transferred across disparate entities (Williamson, 1981; Cheon et al, 1985);

- In terms of 'ownership and control' under Transaction Cost Theory (Williamson, 1985) and of 'the use an asset in the transaction' under Residual Theory (Lee et al, 2004);

- As a 'contract under which one or more persons (principals) engage another person (agent) to perform some service on their behalf which involves some decision making authority to the agent', under the Agency Cost Theory (Jensen and Meckling, 1976).

The governance mechanisms involved vary from a practitioner point of view, calling for the need to look also into social and inter-organisational theory perspectives, as indicated from the range of contract types (Pyburn, 2002; Lee et al, 2004) listed hereunder:

- Specialised or standardised types of contract;

- Strategic alliances or preferred supplier contract types;

- Joint ventures or equity ownership contract types.

Therefore the governance mechanism is defined by Lee et al. (2004); based upon Lacity and Willcocks (1998), as:

- the outcome of a decision made by a firm on the extent to which a transaction should be vertically integrated, the extent to which the firm shall relinquish control of transaction fulfilment - the form of outsourcing arrangement or contract between the vendor and the customer, and

- the duration for which the firm shall commit to a transaction decision - the contract duration.

\section{IT Strategy}

Henderson and Venkatraman (1993) argue that IT strategy should be elevated from its traditional internal focus so as to address external issues of how the firm is positioned in the IT marketplace (Kefi and Kalika, 2005). In the case of IT outsourcing vendor firms, IT strategy inherently plays a key role in the operations aspect of IT product or service provision to the customer. Therefore the constructs which are expected to compose it include the degree of specialisation of the IT service or product provided by the vendor or of the market it targets and the strategic implementation of IT (IT strategy) to conduct the arrangement (Kefi et al, 2005 based upon measures defined by Henderson and Venkatraman, 1993). Both factors are seen as highly relevant especially when considering outsourcing vendor firms as microenterprises. Hakannson and Schenota (1995) position the size of an organization as one structural property for a customer-vendor relationship alongside with centralization, specialization and configuration. Micro enterprises often overcome barriers to success by emphasising focus on a particular product segment or a particular market (Rui and Nainjing, 2006; Wolff and Pett, 2000). Mahnke, Overby and Vang (2003) also challenge the assumption that firms, including small ones, use IT for cost reduction purposes rather than for coordination and collaborative purposes.

\section{Organisation Infrastructure}

Currie and Suhomlinova (2006) link organizational size to a typology of organizational structures that range from a simple structure (centralized, low on functional specialization and formalization) to a bureaucratic one (decentralized, high on functional specification and formalization). 
The organization structure in micro enterprises is described as typically informal, but highly centralised, which provides strength in decision-making and rapid implementation of change which is a critical element in an IT organization $(\mathrm{Hu}$ and Zhang, 2005, Holmes and Gibson, 2001). Measures applied for organisation infrastructure are most commonly found in organization theory and IS studies (Bergeron et al, 2003) and include the degree of:

- Specialisation _ - norizontal differentiation; measured by number of distinct job titles in organization chart;

- Vertical differentiation - number of the organization's levels in its management hierarchy below top management level;

- Professionalisation - the percentage of professional staff members in the organization;

- Formalisation -the extent to which rules, procedures and activities are written;

- Centralisation - the ratio of managers to total employees. (Hu et al, 2011; Paulson and Stump,1979; Damanpour,1991; Blau et al,1966; Pugh et al,1969).

\section{Methodology}

Desai (1990, p.69) affirms that 'whilst all research studies must adhere as closely as possible to standards of scientific method, the objective of a research study may favour certain modifications in research design and techniques'. Indeed, Desai (1990) also asserts that 'the dimensions of research design ...are not to be regarded as separate or independent of one another.... the various parts of design must fit together' (p.72).Thus the research methodology has allowed for both deductive as well as inductive logic to be applied at different phases of the research methodology design, a practice that is often applied in research (Swanson and Holton, 2005). In this manner, the research has sought to combine a high element of rigour in research as well as a degree of flexibility in allowing for new potential insights and understanding of the context under study. Therefore the conceptual model is initially tested using a quantitative approach, involving a survey to the Maltese IT outsourcing vendor population. Through the applicability of Structural Equation Modeling to the data collected, a best fitting model is derived. A qualitative approach involving a multiple Case study amongst six micro-enterprises is then applied to empirically validate the model, thus allowing for a deductive approach, whilst ensuring rigour and robustness of the results (Irani et al., 1999; Dubé and Paré, 2003).

\section{The Survey}

A survey, using a five point Likert scale questionnaire, was conducted among all 126 IT vendors in Malta to test the conceptual model. The decision to survey all IT vendors in Malta is essential considering the micro firm Maltese context, where sensitivity for provision of information by respondents inherently tends to be high, leading to a higher possibility of response bias or lack of response (Yin, 1994). A questionnaire is developed following a series of primary interviews with various stakeholders as well as after taking into account other similar tested and validated measures as indicated in further detail in Table 1 below. 
Table 1 Constructs and Survey Questions

\begin{tabular}{|c|c|c|c|c|}
\hline Qn. & Question Subject & Construct & Scale & Supporting Research \\
\hline 1 & Size of organisation & & $\begin{array}{l}\text { 1. 1-10 employees } \\
\text { 2. 11-50 employees } \\
\text { 3. 51-250 employees }\end{array}$ & \\
\hline 2 & $\begin{array}{l}\text { Flat/informality/ } \\
\text { Decentralisation }\end{array}$ & $\begin{array}{l}\text { Organisation } \\
\text { infrastructure }\end{array}$ & 5 point Likert scale 1 & $\begin{array}{l}\text { Bergeron et al, 2003; } \\
\text { Miller et al.,1991; } \\
\text { Paulson and Stump, 1979; } \\
\text { Damanpour, 1991; } \\
\text { Blau et al., 1966; } \\
\text { Pugh et al., 1969 }\end{array}$ \\
\hline 3 & $\begin{array}{l}\text { Outsourcing } \\
\text { relationship type }\end{array}$ & $\begin{array}{l}\text { Business } \\
\text { strategy }\end{array}$ & $\begin{array}{l}\text { 1. Fee for service } \\
\text { 2.Less formal agreement } \\
\text { 3. Buy in }\end{array}$ & $\begin{array}{l}\text { Lee et al., } 2004 \text { based upon Lacity } \\
\text { and Willcocks, 1998; Lacity et al, } \\
2010\end{array}$ \\
\hline 4 & Relationship duration & $\begin{array}{l}\text { Business } \\
\text { strategy }\end{array}$ & $\begin{array}{l}\text { 1. Less than } 3 \text { years } \\
2.3 \text { years or more }\end{array}$ & Same as for Qn. 3 \\
\hline 5 & $\begin{array}{l}\text { Product/Service } \\
\text { offered }\end{array}$ & & $\begin{array}{l}\text { 1. Software design and development } \\
\text { 2. Hardware related } \\
\text { 3. Application service provision } \\
\text { 4. Training and Education } \\
\text { 5. Data and facilities management } \\
\text { 6. Call centre services } \\
\text { 7. Information security management }\end{array}$ & $\begin{array}{l}\text { Loh and Ventkatraman, 1992; } \\
\text { Fish and Seydal, } 2006\end{array}$ \\
\hline 6 & $\begin{array}{l}\text { Specialist } \\
\text { product/service }\end{array}$ & IT strategy & 5 point Likert scale & $\begin{array}{l}\text { Kefi et al., } 2005 \text { based upon measures } \\
\text { defined by Henderson and } \\
\text { Venkatraman, 1993; } \\
\text { Al-Qirim, 2010; } \\
\text { Blili and Raymond, 1993; } \\
\text { Myra, } 1993\end{array}$ \\
\hline 7 & $\begin{array}{l}\text { Commitment to } \\
\text { strategic use of IT }\end{array}$ & IT strategy & 5 point Likert scale & Same as for Qn. 6 \\
\hline 8 & Strategic orientation & 要 & $\begin{array}{l}\text { 1. Focus on rapid allocation of its } \\
\text { resources at a faster rate than its } \\
\text { competitors } \\
\text { 2. Focus on cost reduction and } \\
\text { efficiency seeking methods } \\
\text { 3. Focus on effectiveness rather than } \\
\text { on efficiency Focus on problem } \\
\text { solving, analysis } \\
4 \text {. Focus on continuous search for } \\
\text { new opportunities and } \\
\text { experimentation with potential } \\
\text { responses to business changes } \\
5 \text {. Readiness to take high risks in } \\
\text { resource allocation or choices of } \\
\text { products/markets }\end{array}$ & $\begin{array}{l}\text { Instrument by Venkatraman (1989) } \\
\text { for strategic orientation previously } \\
\text { validated in small business context } \\
\text { by Raymond et al. (1995). } \\
\text { Bergeron et al., 2003; } \\
\text { Hooper et al, } 2010 .\end{array}$ \\
\hline 9 & $\begin{array}{l}\text { Impact of IT } \\
\text { infrastructure }\end{array}$ & $\begin{array}{l}\text { Organisation } \\
\text { infrastructure }\end{array}$ & 5 point Likert scale & $\begin{array}{l}\text { Bergeron et al, 2003; } \\
\text { Tao and Teng, } 2011\end{array}$ \\
\hline 10 & $\begin{array}{l}\text { Perceived strategic } \\
\text { alignment }\end{array}$ & $\begin{array}{l}\text { Competitive } \\
\text { potential }\end{array}$ & 5 point Likert scale & $\begin{array}{l}\text { Henderson and Venkatraman, 1993; } \\
\text { Luftman, Lewis \& Oldach ,1993; } \\
\text { Marrone and Kolbe, } 2010\end{array}$ \\
\hline
\end{tabular}

\footnotetext{
${ }^{1}$ Ranging from Fully Agree to Fully Disagree
} 
In view that this was the first study of its kind in Malta, it was essential to look into other tested models in order to safeguard high levels of reliability and construct validity. Questionnaires were sent by post to all IT firms in Malta; of which a 52 percent valid response rate was achieved after a target four week period for replies.

Table 2 below produces some descriptive statistics.

Table 2 Descriptive Statistics

\begin{tabular}{|c|c|c|}
\hline Question & Median & Mode \\
\hline 1 & 1 & 1 \\
\hline 2 & 4 & 4 \\
\hline 3 & 1 & 1 \\
\hline 4 & 1 & 1 \\
\hline 5 & 1 & 1 \\
\hline 6 & 4 & 4 \\
\hline 7 & 4 & 4 \\
\hline 8 & 4 & 2 \\
\hline 9 & 4 & 4 \\
\hline 10 & 4 & 4 \\
\hline
\end{tabular}

Of particular interest are:

i) the equal value of the mode and median of the responses of the question requesting the firm size (question 1). The mode, particularly indicates a high incidence of the value representing micro-enterprises;

ii) the mode of the responses of the question requesting the firm service provision (question 5) indicates a high incidence of the value representing software provision. Similarly, the median indicates centrality with respect to such value;

iii) a tendency towards contract-based relationships (as noted by the median and mode for the responses of question 3) and that are of a short term (as noted by equal value for the, median and mode for responses of question 4 ).

\section{Validation through a Multiple Case Study}

\section{Construct Validity}

The initial data collection exercise via the questionnaire and the subsequent data analysis via SEM modelling are seen as an initial step in ensuring construct validity. Although the questionnaire appears to have targeted a majority of microenterprises, it is believed that, given that this particular study is the first of its kind in Malta, a further focus on microenterprises would be necessary to validate the findings further. Indeed, the combination of both survey and case study approach in the field of IT related research is believed to be able to increase the robustness of results because findings could be strengthened through triangulation (Bin Md Basir, 2006; Fernandez, 2005, p.47).

Furthermore a multiple Case study type was considered for this study given that, as stated by Yin (2003), its 'goal is to replicate findings across cases'. It is also argued that although such a method may be time consuming and expensive, the evidence created by this type of study is considered robust and reliable (Baxter and Jack, 2008) and serves to augment external validity (Voss et al. , 2002).

For the purpose of this study, ten microenterprises were thus invited to participate in the multiple case study through an interview. It is argued that 'any sample exceeding ten cases would indeed make it virtually impossible for the researcher to analyze adequately the staggering amount 
of data to be collected' (Audet and d'Amboise, 2001). Additionally, it could also be considered that the sample size of a case study is a function of time, manageability and availability of resources (Akalu, 2002). Four of the ten firms selected indicated, albeit not verbally stated, a reluctance to schedule an interview meeting. Within the limited time constraints, the study was therefore conducted with six firms. Indeed, as recommended by Eisenhardt (1989, p.545), a sample size between four to ten organizations should suffice for a valid case study research (see Appendix 1).

A semi-structured approach to interviewing is applied. The set of interview questions are reviewed and discussed with an independent researcher, prior to their applicability for this purpose. Whilst (as indicated in the Appendix 2), the questions keep the preliminary quantitative work into consideration, it tries to avoid sole dependence on deductive reasoning (Glaser and Strauss, 1967).

In all cases, the set of interview questions were sent ahead of the interview scheduled with the respondent, on the understanding that the respondent would know beforehand what to expect of the session and have time to think about the answers. Additionally it is seen to serve as a means to engender confidence and trust with the respondent and thus ensure cooperation in response. As also confirmed by Mizzi (2010), 'the Maltese entrepreneur is typically reluctant to share information that could be of commercial value to his competitors. Maltese entrepreneurs are fiercely competitive'. Indeed, such sensitivity could be more accentuated in micro-enterprises. Hence ways were sought to alleviate concerns of divulging of information, such as avoidance of tape recording of the interview. The interviews were recorded in note form instead, and following consent with the respondents. The notes were reviewed the same day or the day after the interview and the case analysis was performed as soon as possible, while the information concerning the case was still fresh in the mind of the researcher.

Apart from the interviews, reference is also made to the respondent firms' websites and to brochures, where available, as a means to achieve data triangulation. Baxter and Jack (2008) quote Knafl and Breitmayer (1989) in that 'the collection and comparison of this data enhances data quality based on the principles of idea convergence and the confirmation of findings'.

\section{Internal Validity}

Yin (1994) discusses pattern matching or pattern coding as the most desirable analytic strategy in case study research. Thus, the emerging framework (empirically based pattern) is compared with the conceptual framework (the predicted pattern).

\section{External Validity}

One of the reasons that Yin (2003) indicates a preference towards multiple case studies is that external validity can be strengthened, depending upon the results. Replication logic is sought in the selection of the sampled firms. Firms that are seen to be different are iteratively compared and contrasted.

\section{Reliability}

As suggested by Schell (1992), a case study protocol is devised such that the interview questions are documented and are based on the constructs that these questions are meant to measure. Both the documentation related to the research process as well as the data for each case are documented, organised and presented in a logical and meaningful way so as to establish a valid and reliable case database.

\section{Data Analysis and Findings}

The Best Fit Model through SEM Approach and Data Analysis

The data resulting from the survey is analysed by means of Structural Equation 
Modeling (SEM) with the aid of Lisrel 8.72 tool. SEM is selected since:

- It analyzes the relations between latent and observed variables (Kline, 1998); dealing not only with single, simple or multiple linear regression but with a system of regression equations (Nachtigall et al., 2003);

- It is contended by Gefen, Straub and Boudreau (2000) 'even a casual glance at the IT literature suggests that SEM has become de rigueur in validating instruments and testing linkages between constructs' (p.4).

- It is a tried and tested method in researches related to IT outsourcing and strategic alignment.

The path model resulting through the use of SEM is shown below.

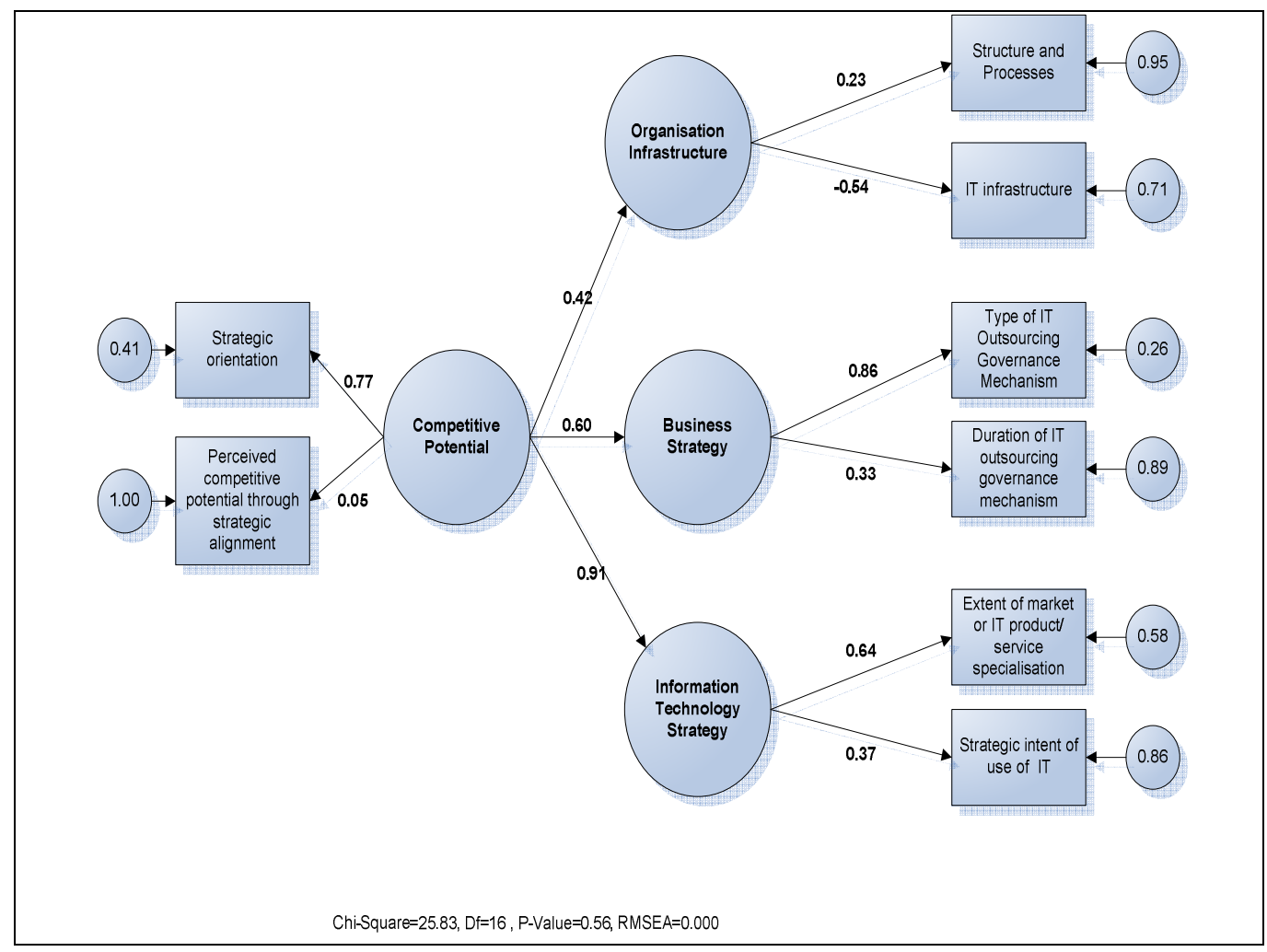

Fig 2. Resulting Path Model

On the other hand, Lisrel 8.72 SEM tool has enabled simultaneous evaluation of the structural model proposed and the measurements used for the model. This was achieved through the computation of a number of goodness of fit measures applied by the software tool itself. As argued by Chin and Newsted (1995) there is no agreed goodness of fit measure for SEMs. This paper has adopted a similar method applied by Kefi et al (2005) in using absolute, incremental and parsimonious goodness of fit indices to estimate the structural model, in line with recommendations by Rousel et al (2002).

Table 3, below, presents the indices derived by Lisrel 8.72 on the structural model proposed and the recommended values by various sources. 
Table 3 Goodness of Fit Measures

\begin{tabular}{|c|c|c|}
\hline \multirow[b]{2}{*}{ Goodness of fit measure } & Resulting value & \multirow{2}{*}{\begin{tabular}{l}
\multicolumn{2}{c}{ Recommended Value } \\
(Sources: Joreskog and Sorbom, 1993; \\
Kefi et al, 2005; Kline,2005)
\end{tabular}} \\
\hline & Absolute Indices & \\
\hline Chi-square & 25.83 for $16 \mathrm{df}$ & $\begin{array}{l}\text { None } \\
\end{array}$ \\
\hline $\begin{array}{l}\text { Ratio of Chi-square to degrees of } \\
\text { freedom }\end{array}$ & 1.61 & $<3$ \\
\hline $\begin{array}{l}\text { Root Mean Square Approximation } \\
\text { (RMSEA) }\end{array}$ & 0.00 & $<0.08$ \\
\hline Root Mean Square Residual (RMR) & 0.18 & Closest to Zero \\
\hline Goodness of Fit Index (GFI) & 0.91 & $>0.9$ \\
\hline \multirow[t]{2}{*}{$\begin{array}{l}\text { Adjusted Goodness of Fit Index } \\
\text { (AGFI) }\end{array}$} & 0.79 & $>0.9$ \\
\hline & Incremental Indices & \\
\hline Normed Fit Index (NFI) & 0.89 & $>0.9$ \\
\hline \multirow[t]{2}{*}{ Comparative Fit Index (CFI) } & 1.00 & $>0.9$ \\
\hline & Parsimonious Indices & \\
\hline AIC & $\begin{array}{c}65.83 \text { (Saturated AIC }= \\
72.00)\end{array}$ & As closest to the saturated model AIC \\
\hline $\begin{array}{l}\text { Expected Cross-Validation Index } \\
\text { (ECVI) }\end{array}$ & $\begin{array}{c}0.86 \text { (Saturated ECVI }= \\
1.1)\end{array}$ & As closest to the saturated model ECVI \\
\hline $\begin{array}{l}\text { Parsimony Goodness of Fit Index } \\
\text { (PGFI) }\end{array}$ & 0.40 & As high as possible \\
\hline
\end{tabular}

Most indices indicated in Table 3 suggest acceptable values to the proposed model. Additionally, as indicated in Table 4 below, the estimated correlations among constructs are not excessively high indicating an acceptable level of distinctiveness between them.

Table 4 Correlations between Latent Constructs

\begin{tabular}{|l|l|c|c|c|c|}
\hline $\begin{array}{l}\text { Latent Construct } \\
\text { Type }\end{array}$ & Constructs & $\begin{array}{c}\text { Organization } \\
\text { Infrastructure }\end{array}$ & $\begin{array}{c}\text { Business } \\
\text { Strategy }\end{array}$ & $\begin{array}{c}\text { IT } \\
\text { Strategy }\end{array}$ & $\begin{array}{c}\text { Competitive } \\
\text { Potential }\end{array}$ \\
\hline Endogenous & $\begin{array}{l}\text { Organization } \\
\text { Infrastructure }\end{array}$ & 1.00 & & & \\
\hline Endogenous & $\begin{array}{l}\text { Business } \\
\text { Strategy }\end{array}$ & 0.25 & 1.00 & & \\
\hline Endogenous & IT Strategy & 0.38 & 0.55 & 1.00 & \\
\hline Exogenous & $\begin{array}{l}\text { Competitive } \\
\text { Potential }\end{array}$ & 0.42 & 0.06 & 0.91 & 1.00 \\
\hline
\end{tabular}

The correlations (standardised regression coefficients) pose another form of evaluation. According to Cohen (1988), correlations between 0.10 and 0.29 represent small influence, correlations between 0.30 and 0.49 represent medium influence, and correlations between 0.5 and 1.0 represent large influence. According to the model, the correlation between competitive potential and IT strategy (0.91) represents a large influence that for Business Strategy (0.60) represents a medium influence, whilst that for organisation infrastructure (0.42) represents a small influence.

Additionally the resulting path model, shown in Fig 2, indicates the effect of competitive potential on IT strategy, which accounts for 82 percent of its variance $\left(0.91^{2}\right)$ followed by that on Business Strategy, which accounts for 36 percent of its variance $\left(0.60^{2}\right)$, and finally on the 
Organisation Infrastructure which accounts for 16 percent of its variance $\left(0.42^{2}\right)$.

The results also indicate that the competitive potential accounts for 59 percent $\left(0.77^{2}\right)$ in the variance of the vendor's strategic focus for the firm (e.g. innovative focus, cost reduction focus) and that the IT strategy accounts for 42 percent $\left(0.64^{2}\right)$ in the variance of the specialist nature of the IT product/service or its market.

In essence, the findings indicate that IT product or service offering of the IT outsourcing service provider plays a key role in establishing and sustaining the firm's competitive potential. The strong relationship between IT strategy and the competitive potential of the vendor firms, and the significant corresponding measure variances attributed to both constructs may be further confirmed by various literature contributions. Venkatraman et al. (1991) refers to the convergence of two concurrent forces that define the role for IT within organizations, and hence the IT strategy to be adopted by the vendors - the 'technology push' and the 'competitive pull' experienced by the vendor firms. The technology push is attributed to the dynamic nature of IT which leads to changes in the strategic relevance of IT to organisations (McFarlan et al., 1995). The effect of such changes lead to significant improvements in the price performance ratio of IT and to new modes of IT service provision by third parties (Currie et al., 2003). The developments are also in line with evolvements in the applicability of IT by the Maltese client base. It mainly targets support or operational processes within organisations. In effect, it is used as a means to achieve reduced costs and improved service delivery (Barakao and Gatere, 2008) which may lead to the exploitation of IT capabilities in all the possible areas within a business process. The competitive pull, on the other hand, is a result of intense rivalry which is prevalently high in a small economy like Malta. Briguglio and Cordina (2004) contend that a 'small country cannot support a large number of firms producing a similar product'. In the case of small firms, both Namiki (1985) and Taylor et al. (1990) report a tendency for small firms to focus on a particular product market segment or particular set of customers as a means to overcome their hurdles.

The findings also indicate that the business strategy construct accounts for 74 percent $\left(0.86^{2}\right)$ of the variance in the type of relationship between the vendor and the client and for 11 percent $\left(0.33^{2}\right)$ of the variance in the duration of the relationship. In their study, Kern and Willcocks (2004) find that contract complexity, is 'a significant factor to consider, especially in terms of operability' (p.358). This is particularly so, as stated in Williams (1975), 'in IT outsourcing [whereby] the greater the complexity, the more intensive the demand for interorganisational interactions and hence the higher transaction costs' (as cited in Kern and Willcocks, 2001, p.65). Various studies note such diverse forms of contract complexities or governance mechanisms as contingent to the IT product and service offered by the vendor to the customer on a number of parameters, such as the degree of application of IT induced business transformations in customer organisations (Venkatraman et al., 1991); the longitudinal strategic application of IT (McFarlan et al., 1995); the balanced application of IT for competitive positioning and business operations (Kern and Willcocks, 2001) and the use of IT based on its mature applicability in the customer firm and its use for business integration (Feeny et al., 1989; Kern and Willcocks, 2001). Additionally, Oliver (1990) attributes the stability of an interorganisational relationship as a coping strategy to forestall, forecast or absorb uncertainty in order to achieve an orderly reliable pattern of resource flows and exchanges' (Kern and Willcocks, 2001, p.66). Such stability is inferred too by Kern and Wilcocks (2001) as the continuity of the relationship focussing on the contractual time frame and/or expected continuity of the outsourcing relationship' (p.66).

The resulting model also indicates that organisation infrastructure construct just 
accounts for only 5 percent $\left(0.23^{2}\right)$ in the variance of the organisation structure and processes. Lawrence and Dyer (1993) identify a number of organisational forms that they feel are most appropriate for each combination of information complexity, that is, the diversity and uncertainty of the technology and the resource scarcity accentuated by high competitive potential in the IT sector. For example, a fluid and responsive organisation structure is noted as essential in an organisation dealing with a complex and dynamic environment and high levels of competition (Buono and Kerber, 2010; Carnall, 1990). In addition, Mintzberg (1993) contends that 'many small organisations, however, remain with a simple structure beyond their formative years' (p. 159). The simple structure is defined as 'one where its environment tends to be comprehended and controlled by one individual - the decision maker and is at the same time simple - non sophisticated and non regulated and dynamic - an organic structure'. It is also one that is characterised by the entrepreneurial firm, whereby the classic case is the owner-managed firm. This may indeed be the case, considering that 67 percent of the respondents of the questionnaire leading to the formation of the path model are micro-enterprises.

In conclusion, the model derived through the applicability of Structured Equation Modelling and that is largely based on data from micro-enterprises, confirms a positive relationship between the competitive potential and the coalignment of business, IT strategies and organisation infrastructure, based upon the outcomes of Findings 1, 2 and 3 that are summarised in Table 5 below. The findings appear to follow Henderson and Venkatraman's definition with respect to the 'competitive potential perspective' whereby:

- the IT strategy is defined as the domain that has the greatest strength

- the business strategy is the weaker quadrant which will receive focus and where changes will be addressed by the IT strategy

- the organisation infrastructure is the impacted domain as it is directly affected by change to the business strategy (AbouZeid, 2002; Paap, 2002; Henderson and Venkatraman, 1993; Luftman, Lewis and Oldach, 1993).

Table 5 - Findings through Structured Equation Modelling

\begin{tabular}{|l|l|l|}
\hline No. & Indicative Findings & Outcome \\
\hline 1 & $\begin{array}{l}\text { Competitive potential has a highly significant impact upon the IT } \\
\text { strategy. The competitive potential is in turn highly attributed to the } \\
\text { vendor's strategic focus, whilst the IT strategy is highly attributed to } \\
\text { the specialist nature of the IT product/service or its market }\end{array}$ & $\begin{array}{l}\text { Satisfactory } \\
\text { and in particular on the form of outsourcing relationship. }\end{array}$ \\
\hline 2 & $\begin{array}{l}\text { Competitive potential has a low impact upon the organisation } \\
\text { infrastructure. }\end{array}$ & Satisfactory \\
\hline
\end{tabular}

Specifically, the IT strategy is indeed one major area of focus for a micro-enterprise IT outsourcing vendor, particularly with respect to IT investments made and to the degree of specialisation of the IT product and/or service offered and/or the market targeted. Specialisation may in particular enable such firms to survive in a highly volatile and competitive industry as that for IT. Domberger (1998, p. 51) argues that it may also provide tangible economic benefits to both the vendor and the customer in that, by concentrating on activities in which an organisation is relatively more efficient, total value added is maximised.

\section{Case-Study Data Analysis and Findings}

The outcome of the multiple case study is presented in Table 6 below. 
Table 6 - Findings through the Multiple Case Study approach

\begin{tabular}{|l|l|l|}
\hline No. & Indicative Findings & Outcome \\
\hline 4 & $\begin{array}{l}\text { There is very strong support with respect to the impact that } \\
\text { Competitive potential has upon the IT strategy. Conversely, there is } \\
\text { very strong support with respect to the impact that IT strategy has } \\
\text { upon Competitive potential }\end{array}$ & $\begin{array}{l}\text { Confirms impact } \\
\text { and builds upon } \\
\text { Finding 1 }\end{array}$ \\
\hline 5 & $\begin{array}{l}\text { There is very strong support with respect to the impact that } \\
\text { Competitive potential has the business strategy. Conversely, there } \\
\text { is very strong support with respect to the impact that business } \\
\text { strategy has upon Competitive potential }\end{array}$ & $\begin{array}{l}\text { Confirms impact } \\
\text { Finding 2 }\end{array}$ \\
\hline 6 & $\begin{array}{l}\text { There is very strong support with respect to the impact that } \\
\text { Competitive potential has upon the organisation infrastructure. } \\
\text { Conversely, there is very strong support with respect to the impact } \\
\text { that organisation infrastructure has upon Competitive potential }\end{array}$ & $\begin{array}{l}\text { Confirms impact } \\
\text { and builds upon } \\
\text { Finding 3 }\end{array}$ \\
\hline
\end{tabular}

The key case study findings confirm the findings through the SEM model, whereby an IT outsourcing vendor firm's competitive potential is an influential factor upon the firm's IT strategy, business strategy and organisation infrastructure. They also indicate that competitive potential is shaped by the IT outsourcing vendor firm's IT strategy, business strategy and organisation infrastructure. The findings also lead to conclusions that:

- each strategic and organisational related function needs to be undertaken within the context of influence from and upon the other strategic or organisational function within the IT outsourcing organisation.

- the external environment has an overall influence, albeit indirectly, on the vendor's competitive potential.

\section{Limitations}

The findings of the research need to be interpreted with few limitations in mind. It is seen as a case which cannot be easily replicated. The survey is conducted within a small developing economy, where the IT outsourcing vendor's community amounted to less than 150 firms. Most surveyed firms employed less than 10 often family related employees generally considered as micro-sized organisations in EU. Additionally, the operational proximity of firms in Malta is relatively small and often overlapping, leading towards tendency for mistrust and fear by some firms to divulge information through surveys or even through interviews.

\section{Conclusion}

The research has provided an insight into the competitive potential of micro sized firms offering IT outsourcing products and services operating within a micro European Union island state. The IT outsourcing governance mechanisms as the vendor firms' business strategy are of secondary, albeit significant impact upon the competitive potential of the firms. The IT strategy of IT outsourcing vendors is playing the most significant role, acting as the key 'anchor domain' as termed by Henderson \& Venkatraman (1993) in their Strategic Alignment Modelling for a Competitive Potential perspective. Indeed as these results suggest, the findings indicate that the IT strategy adopted by the IT outsourcing vendor firm is significantly shaped by the specialist nature of the IT product/service and/or its market. The firm's major domain for competitive potential has been largely assessed through cost reductions and efficiency gains within the organisation. The specialist focus in the product/service offer and/or the market reflects the tendency stated earlier with respect to micro-sized firms, as their only means to overcome hindrances to success. 
Ultimately, as confirmed through the case study findings, there is the need for alignment of strategic, organisational and competitive factors within a microenterprise IT outsourcing firm, in order to generate competitive potential that is sustainable. It could be noted that competitive potential cannot be based solely on core capabilities and efforts, which in micro-enterprises can be particularly lacking or constrained in terms of, for example, availability of skills, efforts in research and development, financial depth and effort. Competitive potential is rather a dynamic capability that evolves out of well conceived business strategy, IT strategy and organisation infrastructure that seek to exploit existing competitive advantages and compensate for resource constraints whilst seeking to deliver service and/or product through outsourcing arrangements. Hence IT strategy, business strategy and organisation infrastructure cannot be formulated in isolation, since, essentially, they all have impacted one another.

Last but not least, it is noted that the external environment has an overall influence, albeit indirectly, on the vendor's competitive potential. The form of IT outsourcing relationship, including informal long term sustainable relationships, between the vendor and the customer is only one facet. Equally important are relationships between the vendor and its suppliers, often as indicated, with larger rival IT firms as a means to secure otherwise unsustainable markets in a fiercely competitive environment. Technology developments, as well as global, regional and national economic challenges are also seen as catalysts for changes within the IT vendor organisations themselves which may in turn lead to new opportunities for market growth for long term competitive sustainability. However, such factors merit further elaboration which remains for future research to delve deeper into.

\section{References}

Akalu, M. M. (2002). Projects for Shareholder Value: A Capital Budgeting Perspective, Internet Link, (accessed on 26/2/2011)

Al-Qirim, N. (2010). "E-Commerce Innovations in Jordan: Theoretical Model Development and Implications for Small Businesses," AMCIS 2010 Proceedings, http://aisel.aisnet.org/amcis2010/14

(accessed on 7 March 2011)

Altinkemer, K., Chaturvedi, A. \& Gulati, R. (1994). "Information Systems Outsourcing: Issues and Evidence," International Journal of Information Management, 14, 252-268

Ang, J. S. (1991). 'Small Business Uniqueness and the Theory of Financial Management,' Journal of Small Business Finance 1(1). 1-13

Audet, J. \& d'Amboise, G. (2001). "The Multi-Site Study: An Innovative Research Methodology," The Qualitative Report, 6, http://www.nova.edu/ssss/QR/QR6-

2/audet.html (accessed on 23 August 2010).

Baldacchino, G. (1999). "Small Business in Small Islands: A Case Study from Fiji," Journal of Small Business Management, 37

Barakao, D. G. \& Gatere, P. K. (2008). "Outsourcing Practices of the Kenyan Banking Sector," African Journal of Accounting, Economics, Finance and Banking Research,2

Baxter, P. \& Jack, S. (2008). "Qualitative Case Study Methodology: Study Design and Implementation for Novice Researchers," The Qualitative Report, 13 (4). 554-559

Beeson, I. \& Al Mahamid, S.(2004). “Survey of Strategic Alignment Indicators in Manufacturing Companies in South-West of England," In proceeding of the second 
CEMS Research Student Conference, Bristol, 15 October, 2004.

Bergeron, F., Raymond, L. \& Rivard, S. (2003). 'Strategic Alignment of Information Technology: Performance Outcomes in Small and Medium Sized Firms,' Business Excellence I: Performance Measures, Benchmarking and Best Practices in New Economy, University of Minho, Braga, Portugal, pp. 67-72

Bin Md Basir, H.(2006). "The Interoperability of Strategic Alignment Model in Malaysian Public Institutions of Higher Learning," SITMA , Malaysia

Blau, P. M., Heydebrand, W. V. \& Stauffer, R. E. (1966). "The Structure of Small Bureaucracies," American Sociological Review 31,179-191

Blili, S. \& Raymond, L. (1993). 'Information Technology: Threats and Opportunities for SMEs,' International Journal of Information Management, 13,6,439-448.

Brancheau, J., Janz, B. \& Wetherbe, J. (1996). "Key Issues in Information Systems Management: 1994-1995 SIM Delphi Results," MIS Quarterly, 20, 225-242.

Briguglio, L. \& Cordina, G. (2004). 'Competitiveness Strategies for Small States,' Briguglio, L. and Cordina, G. (Ed). Published by Formatek Malta, for the Commonwealth Secretariat and the University of Malta. ISBN 9909-49-20-4.

Carnall, C. (1990). 'Managing Change in Organisations,' Prentice Hall International (UK) Ltd.

Chan, Y. \& Reich, B. (2007). 'State of the Art IT Alignment, What Have we Learnt?,' Journal of Information Technology, 22, 297315

Chen, S., Duan, Y., Edwards, J. S. \& Lehaney, B. (2006). "Toward Understanding Inter Organizational Knowledge Transfer Needs in SMEs: Insight from a UK Investigation," Journal of Knowledge Management, 10, 3, 623.
Cheon, M. J., Grover, V. \& Teng, J.T.C. (1995). "Theoretical Perspectives on the Outsourcing of Information Systems," Journal of Information Technology, 10, 209219.

Chevez, N. V. (2010). "A Unified Strategic Business and IT Alignment Model, a Study in the Public Universities of Nicaragua," Licentiate Thesis in Computer and Systems Sciences, Royal Institute of Technology, Stockholm, Sweden

Chin, W. \& Newsted, P. R. (1995). 'The Importance of Specification in Causal Modelling: The Case of End-User Computing Satisfaction,' Information Systems Research, 6(1). 73-81

Cohen, J. (1988). 'Statistical Power Analysis for Behavioural Sciences,' New York: Academic Press (2nd. Ed.)

Cragg, P. B. \& Todorova, N. (2005). "Information Systems Strategic Alignment in Small Firms," (accessed on 16 February 2011).

Cronk, J. \& Sharp, J. (1995). “A Framework for Deciding What to Outsource in Information Technology," Journal of Information Technology, 10, 259-267.

Currie, G. \& Suhomlinova, O. (2006). "The Impact of Institutional Forces Upon Knowledge Sharing in the UK NHS: The Triumph of Professional Power and the Inconsistency of Policy," Public Administration, 84(1). 1-30.

Currie, W. (1995). Management Strategy for IT, FT/Prentice Hall.

Currie, W. (2000). "The Supply-side of IT Outsourcing: The Trend towards Mergers, Acquisitions and Joint Ventures," International Journal of Physical Distribution and Logistics Management, 30, 3/4/, 238-254.

Currie, W. L., Desai B., Khan, N., Wang, X. \& Weerakkody V. (2003). "Vendor Strategies for Business Process and Applications Outsourcing: Recent Findings from Field 
Research," Proceedings of the 36th Hawaii International Conference on System Sciences (HICSS'03).

Damanpour, F. (1991). “Organizational Innovation: A Meta-Analysis of Effects of Determinants and Moderators," Academy of Management Journal, 34 (3). 555-590

DiRomualdo, A. \& Gurbaxani, V. (1997). "Strategic Intent for IT Outsourcing," Working Paper ITR-140 - Research in collaboration with the sponsoring organizations of CSC Foundation research program.

Eisenhardt, K. M. (1989). "Building Theories from Case Study Research," Academy of Management Review, 14(4). 532-550.

European Commission (2010). "Enterprise and Industry, Small and Medium Sized Enterprises,"

http://ec.europa.eu/enterprise/policies/s me/promoting-entrepreneurship/craftsmicro-enterprises/(accessed on 1 December 2010).

Feeny, D., Earl, M. \& Edwards, B. (1989). "IS Arrangements to Suit Complex Organisations 2: Integrating the Efforts of Users and Specialists," OXIIM research and discussion paper, Oxford Templeton College.

Fernandez, W. .(2005). "Chapter 5- The Grounded Theory Method and Case Study Data in IS Research: Issues and Design," in D. Hart and S. Gregor (eds.). Information Systems Foundations Workshop: Constructing and Criticising, Canberra: Australian National University E-Press, http://epress.anu.edu.au/info_systems_cita tion.html (accessed on 16 August 2010).

Fish, K. E. \& Seydel, J. (2006). "Where IT Outsourcing is and Where it Is Going: A Study across Functions and Department Sizes," The Journal of Computer Information Systems 46(3):96-103.

Government of Malta.(2010). "National Policy, Vision 2015," https://opm.gov.mt/vizjoni-2015

(accessed on 31 May 2010).

Hadjimanolis, A. (2000). "An Investigation of Innovation Antecedents in Small Firms in the Context of a Small Developing Country," R\&D Management, 30(3). Blackwell Publishers Ltd, UK

Hakannson, H. \& Schenota, I. (1995). 'Developing Relationships in Business Networks,' Routledge, London.

Hale, A. J. \& Cragg, P. B. (1996). "Business Process Re-Engineering in the Small Firm: A Case Study," Proquest.

Hancox, M. \& Hackney, R. (1999). 'Information Technology Outsourcing: Conceptualising Practice in the Public and Private Sector,' Proceedings of the 32nd. Hawaii International Conference on System Sciences,1-15.

Hartog, C. \& Herbert, M. (1986). 'Opinion Survey of MIS Managers: Key Issues,' MIS Quarterly, 10(4).351-361.

Heath, N. (2009). "Cheat Sheet:Outsourcing - Is it in or Out?," Silicon.com, 11 September 2009, silicon.com, (accessed on 10 October 2009)

Henderson, J. C. \& Venkatraman, N. (1993). "Strategic Alignment: Leveraging Information Technology for Transforming Organisations," IBM Systems Journal, 31(1).4-16.

Holmes, S. \& Gibson, B. (2001). 'Definition of Small Business (Final Report),' The University of Newcastle.

Hooper,V. A., Huff, S. L. \& Thirkell, P. C. (2010). "The Impact of IS-Marketing Alignment on Marketing Performance and Business Performance," ACM SIGMIS Database, 41,1

Hu, T., Zhang, X. \& Teng, W.-Y. (2011). "Understanding Information Technology Configuration in Business Diversification: A Political View," Information Technology Journal, 10, 470-477 
Jensen, M. C. \& Meckling, W. H. (1976). "Theory of the Firm: Managerial Behaviour, Agency Costs and Ownership Structure," Journal of Financial Economics, 3, 305-360

Johnson, G. \& Scholes, K. (1993). 'Exploring Corporate Strategy,' Prentice Hall Publications

Jouirou, N. \& Kalika, M.(2004). "Strategic Alignment: a Performance Tool (An Empirical Studyo SMEs)," Proceedings of the Tenth Americas Conference on Information Systems, (New York: 2004).

Kaul, M. (1997). "The New Public Administration: Management Innovations in Government," Public Administration and Development, 17, 13-26

Kearns, G. S. \& Lederer, A. L. (2000). "The Effect of Strategic Alignment on the Use of IS Based Resources for Competitive Advantage," Journal of Strategic Information Systems, 9, 265-293

Kefi, H. \& Kalika, M. (2005). "Survey of Strategic Alignment Impacts on Organizational Performance in International European Companies," Proceedings of the 38th Hawaii International Conference on System Sciences, 1-10

Klepper, R. (1994). 'Outsourcing Relationships,' in Managing IT with Outsourcing, Idea Group Publishing, 218243

Klepper, R. (1995). "The Management of Partnering Development in I/S Outsourcing," Journal of Information Technology, 10, 249-258.

Kline, R. B. (1998). 'Principles and Practice of Structural Equation Modelling,' The Guilford Press, NY, USA

Korvela, H. \& Packalen, K. (2010). "Looking Beyond the Veil- What Makes the MicroOrganisation End-User Developers Tick?," AMCIS 2010 Proceedings, 16th Americas Conference on Information Systems, Lima, Peru, August 12-15, 2010
Kudelski \& Partner, A. G. (2005). 'Business Reengineering and Process Management,' Zurich, www.kudelski.ch

Lacity, M. C. \& Hirschheim, R. (1993). Information Systems Outsourcing: Myths, Metaphors and Realities, John Wiley and Son, UK.

Lacity, M. C., Khan, S., Yan, A. \& Willcocks, L. P. (2010). "A Review of the IT Outsourcing Empirical Literature and Future Research Directions," Journal of Information Technology, 25, 395-433.

Lacity, M. C. \& Willcocks, L. P. (2001). Global Information Technology Outsourcing : In Search of Business Advantage, John Wiley and Sons ISBN 0471899593.

Lawrence, P. R. \& Dyer, D. (1983). 'Renewing American Industry,' New York, Free Press

Lee, J.-N., Miranda, S. M. \& Kim, Y.-M. (2004). "IT Outsourcing Strategies: Universalistic, Contingency and Configurational Explanations of Success," Information Systems Research, 15(2).110131

Levina, N., \& Ross, J. (2003). "From the Vendor's Perspective: Exploring the Value Proposition in IT Outsourcing," MIS Quarterly 27(3).331-364

Luftmann, J. N., Lewis, P. R. \& Oldach, S. H. (1993). "Transforming the Enterprise: The Alignment of Business and IT Strategies," IBM Systems Journal, 32(1). 198-221

Mahesha, K. \& Lawson, R. (2006). "Barriers to Adopting ICT and e-commerce with SMEs in Developing Countries: An Exploratory Study in Sri Lanka," CollECTeR '06, Adelaide

Mahnke, V., Overby, M. L. \& Vang, J. (2003). "Strategic IT-Outsourcing: What do we Know and Need to Know," Draft Version, 133, www.druid.dk/uploads/tx_picturedb/ds20 
03-892.pdf (accessed on 22 December 2009).

Marrone, M. \& Kolbe, L. M. (2010). "Providing More than Just Operational Benefits: An Empirical Research," MKWI 2010, Performance Management / ITControlling 287, (accessed on 7 March 2011)

McFarlan, F. W. \& Nolan, R. . (1995). "How to Manage an IT Outsourcing Alliance," Sloan Management Review.

Miller, C. C., Glick W. H., Wang, Y. D. \& Huber, G. P. (1991). "Understanding Technology-Structure Relationships: Theory Development and Meta-Analytic Theory Testing," Academy of Management Journal 34(2). 370-399.

Ministry for Investment, Industry and Information Technology (MIT\&I). (2007). 'Information and Communications Technologies - Business Directory,' Government of Malta.

Mintsberg, H. (1993). Structure in Fives, Designing Effective Organisations, Prentice Hall Publications.

Mizzi, M. (2010). "Innovation and the Maltese SME," http://grtu.net , (accessed on $26 / 10 / 2010$ ).

Muhamad, M. R. \& Ashari, H. (2005). 'The Alignment of Competitive Priorities, Process Structure, and IT Applications, and its Effect on Firm Performance: A Proposed Conceptual Model,' 35th International Conference on Computers and Industrial Engineering, Turkey, 1403-1408.

Nachtigall, C., Kroehne, U., Funke, F. \& Steyer, R. (2003). '(Why) Should we Use SEM? Pros and Cons of Structural Equation Modeling,' Methods of Psychological Research Online, 8(2).1-22

Namiki, N. (1988). "Export Strategy for Small Business," Journal of Small Business Management, 26, 32-37.
National Statistics Office (2005). "Survey on Information and Communications Technology - Usage of Enterprises 2003," www.nso.gov.mt, Malta

Neiderman, F., Brancheau, J. C. \& Wetherbe, J. C. (1991). "Information Systems Management Issues for the 1990s," MIS Quarterly, 16(4).474-500.

Oliver, C. (1990). "Determinants of Interorganisational Relationships: Integration and Future Directions," Academy of Management Review, 15/2, 241-265.

Paap, R. (2001). Introduction to Strategic Alignment, Quinnipac University, USA, Idea Group Publishing

Packalen, K. (2010). "ICT Capabilities and Possibilities in Micro-firms: A Study of micro-firms in the Aland Islands Arcipelago," 23rd Bled eConference eTrust: Implications for the Individual, Enterprises and Society, June 20-23, 2010, Bled, Slovenia

Paulson, S. K. \& Stump, A. L. (1979). 'Small Business and the Theory of Small Bureaucracies,' American Journal of Small Business, 3(3).34-47.

Pinto, R. F. (1998). "Innovations in the Provision of Public Goods and Services," Public Administration and Development. 18, 387-397.

Porter, M. (1990). 'The Competitive Advantage of Nations,' New York: The Free Press

Prasad, S. \& Tata, J. (2009)."Microenterprise Quality," International Journal of Quality \& Reliability Management, 26(3). $234-246$

Pugh, D. S., Hickson, D. J., Hinings, C. R. \& Turner, C. (1969). "The Context of Organisation Structures," Administrative Science Quarterly 14(2). 91-114. 
Pyburn, P. (2002). 'Business Process Outsourcing - A Framework for Governance,' Presentation.]

Roussel, P., Durrieu, F., Campoy, E. \& El Akremi, A. (2002). 'Methodes d'Equations Structurelles: Recherche et Applications en Gestion,' Economica

Rui, S. \& Nainjing, W. (2006). "The Research in Innovation Work Environment of High Tech SMEs," 20-24

Schell, C. (1992). "The Value of the Case Study as a Research Strategy," Manchester Business School.

Simons, K. (2002). "Information Technology and the Dynamics of Firm and Industrial Structure: The British IT Consulting Industry as a Contemporary Specimen," Centre for Economic Policy Research,

http://www.cepr.org/default_static.htm

Srivastava, S., Arora, S. \& Grover, N. (2010). "Outsourcing: As a Competitive Strategy," AIMS International Conference on Valuebased Management, August 11-13, 2010, 901

Streeten, P. (1993). "The Special Problems of Small Countries," World Development, 21,2,197-202

Sum, C., Kow, L. S. \& Chen, C. (2004). 'A Taxonomy of Operations Strategies of High Performing Small and Medium Enterprise in Singapore,' International Journal of Operations and Production Management, 24(3). 321-345

Taylor, B., Giinsky, A., Hilmi, A., Hahn, D. \& Grab, U. (1990). "Strategy and Leadership in Growth Companies," Long Range Planning, 23(3). 66-75.

Tonurist, P. (2010). "What is a 'Small State' in a Globalising Economy?," Halduskultur, Administrative Culture 11 (1). 8-29

Van Dijk, M. P. (2000). "The Export Potential of SMEs in Southern
Mediterranean Countries, a Study in the Light of the FTA between the SMC and the EU," Economic Faculty, Erasmus University.

Venkatraman, N. (1989). "Strategic Orientation of Business Enterprises: The Construct, Dimensionality and Measurement," Management Science, 35(8). 942- 956

Voss, C., Tsikriktsis, N. \& Frohlich, M. (2002). "Case Research in Operations Management," International Journal of Operations and Production Management, 22(2). 195-215.

Williamson, O. E. (1985). 'The Economic Institutions of Capitalism,' Free Press, New York.

Windrum, P. \& Berranger, P. (2002). "The Adoption of E-Business Technology by SMEs," Infonomics Research Memorandum Series, Maastricht Economic Research Instititute on Innovation and Technology

Wolff, J. A. \& Pett, T. L. (2000). 'Internationalisation of Small Firms: An Examination of Export Competitive Patterns, Firm Size and Export Performance,' Journal of Small Business Management, 34-56.

World Economic Forum (2010). The Global Competitiveness Report 2009-2010, (accessed on December 2010).

Yin, R. K. (1994). Case Study Research: Design and Methods, Second Edition, Newbury Park CA: Sage Publications.

Yin, R. K. (2003). Case Study Research, Design and Methods, Third Edition, Newbury Park CA: Sage Publications.

Zeffane, R. (1995). "The Widening Scope of Inter-Organisational Networking: Economic, Sectoral and Social Dimensions," Leadership and Organisation Development Journal, 16, 4. 
Appendix 1 Company Table

\begin{tabular}{|l|l|l|l|l|l|l|}
\hline Company & A & B & C & D & E & F \\
\hline Home Base & Malta & Malta & Malta & Malta & Malta & Malta \\
\hline $\begin{array}{l}\text { Highest } \\
\text { Market } \\
\text { geographic } \\
\text { scope }\end{array}$ & Overseas & Malta & Malta & Malta & Overseas & Malta \\
\hline $\begin{array}{l}\text { Market } \\
\text { Share }\end{array}$ & $90 \%$ & $80 \%$ & $65 \%$ & $85 \%$ & $\begin{array}{l}\text { Figure not } \\
\text { divulged- } \\
\text { though it is } \\
\text { cited that the } \\
\text { majority } \\
\text { market share } \\
\text { is overeas }\end{array}$ & $\begin{array}{l}\text { Figure not } \\
\text { divulged- } \\
\text { though it is } \\
\text { majority the } \\
\text { market share } \\
\text { is in Malta }\end{array}$ \\
\hline $\begin{array}{l}\text { Core } \\
\text { Product }\end{array}$ & Software & $\begin{array}{l}\text { Software and } \\
\text { Infrastructure }\end{array}$ & Software & $\begin{array}{l}\text { Software and } \\
\text { Infrastructure }\end{array}$ \\
Companies are not referenced by name to protect their identity and confidentiality. & $\begin{array}{l}\text { Software } \\
\text { Software }\end{array}$ \\
\hline
\end{tabular}

Appendix 2 Interview questions

\begin{tabular}{|c|c|c|c|}
\hline Question & Content & Conceptual model Item & $\begin{array}{l}\text { Reasoning } \\
\text { targeted }\end{array}$ \\
\hline $\begin{array}{l}\text { 1. The Company } \\
\text { and its structure }\end{array}$ & Overview of company structure & $\begin{array}{l}\text { Organisation Infrastructure } \\
\text { (Construct) }\end{array}$ & $\begin{array}{l}\text { Deductive with an } \\
\text { element } \\
\text { inductive } \\
\text { reasoning }\end{array}$ \\
\hline $\begin{array}{l}\text { 2. The Business } \\
\text { Strategy }\end{array}$ & $\begin{array}{l}\text { Overview of: } \\
\text { - } \quad \text { the firm's new IT products } \\
\text { /services and new markets } \\
\text { key IT outsourcing projects } \\
\text { offerred and whether they involve } \\
\text { short/long term contracts, } \\
\text { strategic alliances with the client }\end{array}$ & $\begin{array}{l}\text { Business Strategy } \\
\text { (Construct) }\end{array}$ & Deductive \\
\hline $\begin{array}{l}\text { 3. Competitive } \\
\text { potential }\end{array}$ & $\begin{array}{l}\text { Assess how and what factors make the } \\
\text { company different from competitors }\end{array}$ & $\begin{array}{l}\text { Competitive potential } \\
\text { (Construct) }\end{array}$ & $\begin{array}{ll}\text { Deductive } & \text { with an } \\
\text { element } & \text { of } \\
\text { inductive } & \\
\text { reasoning } & \end{array}$ \\
\hline 4. IT Strategy & $\begin{array}{l}\text { Overview and assessment of IT } \\
\text { services offered, including market, } \\
\text { pricing and investments made }\end{array}$ & $\begin{array}{l}\text { IT strategy } \\
\text { (Construct) }\end{array}$ & $\begin{array}{lr}\text { Mainly } & \text { deductive } \\
\text { with a minor } \\
\text { element } \\
\text { inductive } \\
\text { reasoning } \\
\end{array}$ \\
\hline 5. General & $\begin{array}{l}\text { Seek through interviewee's experience, } \\
\text { whether an IT outsourcing company's } \\
\text { competitive potential influences the } \\
\text { Company's business strategy, its IT } \\
\text { strategy and its company formation. }\end{array}$ & $\begin{array}{l}\text { Influence of competitive } \\
\text { potential on business } \\
\text { strategy, IT strategy and } \\
\text { organisation infrastructure } \\
\text { (Link) }\end{array}$ & $\begin{array}{l}\text { Partly deductive } \\
\text { and inductive }\end{array}$ \\
\hline
\end{tabular}

